\title{
THE GOVERnANCE OF GLOBALIZATION: THE POLITICAL ECONOMY OF ANGLO-AMERICAN HEGEMONY, 1793-2003
}

\author{
PATRICK KARL O'BRIEN
}

CESIFO WORKING PAPER NO. 1023

CATEGORY 8: RESOURCES AND ENVIRONMENT

SEPTEMBER 2003

An electronic version of the paper may be downloaded

- from the SSRN website: Www.SSRN.com

- from the CESifo website: www.CESifo.de 


\title{
THE GOVERnANCE OF GLOBALIZATION: THE POLITICAL ECONOMY OF ANGLO-AMERICAN HEGEMONY, 1793-2003
}

\begin{abstract}
Modern globalization (which includes free flows of trade and factors of production across frontiers, stable rates of exchange, the containment of warfare and mercantilism, the preservation of the environment and latterly the protection of cities against rogue states and terrorism) are among the public goods provided for the world economy as a whole are represented as a beginning outcome of 6 decades of "hegemony" exercised by governments in Washington from 1941 to 2003. The view promulgated largely by Anglo-American social scientists that the United Kingdom (and before that other powers) also supplied significant public goods for the international order has been degraded in this paper into theory without history. In short the assertion that American Hegemony can be perceived as a succession to the Pax Britannica from 1793-1914 is virtually a myth.
\end{abstract}

JEL Code: N10, A1.

\author{
Patrick Karl O'Brien \\ Economic History Department \\ London School of Economics \\ Houghton Street \\ London WC2A $2 A E$ \\ England \\ p.o’brien@lse.ac.uk
}

This paper was completed during my tenure as a Visiting Research Fellow at the Center for Economic Studies, University of Munich. I am very grateful to the Center for excellent support services and intellectual stimulus provided there in July, 2003. 


\section{Hegemony as an Anglo-American Succession}

Gramsci, who first formulated the concept of hegemony, recognized that power included a combination of coercion and consent. In their scholastic definitions and lengthy elaborations upon Gramsci's notion theorists (located largely within the Anglo-American social sciences of international relations, economics, politics and sociology) have attempted to make a historical case that hegemony and hegemons have been persistent and systemic components of the geopolitical and economic order within which states have operated at least since the Peace of Westphalia and conceivably for centuries before 1648. My essay proposes to argue that since Rome no other state (and particularly Great Britain) has deployed hegemonic power or anything comparable to the combination of domination by force and leadership by consent, exercised by governments of the United States between 1941 and 2001 . Indeed, before the entry of America into the Second World War, no emperor, monarch, ruling oligarchy or sovereign assembly pretended to formulate and enforce rules, designed to shape and stabilize an international order for the operation of competition and co-operation among states. Even when policies pursued by other leading powers of their day had some discernible but unintended consequences of curbing the violence and mitigating the inefficiencies associated with an otherwise anarchic system of geopolitical relations and international commerce, the scale, scope, intensity and duration of their ad hoc actions cannot be compared with the (albeit self-interested) strategies pursued by the United States over the past seven decades.

All other states selected by scholars and commentators as hegemons (or even as proto or neo hegemons) do not deserve that accolade. ${ }^{1}$ The historical record does not allow for the representation of any previous great power (operating within a world system of competing states) as one whose status depended to any significant degree upon a widespread recognition 
that the policies it pursued: contained inter-state violence, facilitated access to international water and airways and promoted the diffusion of labour, capital and useful knowledge across frontiers; let alone (to take two entirely modern global concerns) that its actions safeguarded the environment and protected foreign populations against terrorism. Whereas all these 'public goods' supplied for the world as a whole (voluntarily and unwillingly, effectively and ineffectively, with benign and malign intent) by the United States since the Second World War seem to merit the depiction of Washington's power as hegemonic.

In short only the United States has ever created conditions, allocated resources and displayed intentions to formulate and enforce rules for a more stable and effective operation of political, economic and cultural relations between states. Nevertheless, social scientists have supposedly perceived and (some purport to have measured) increases in security and prosperity which they have correlated with actions taken by a succession of "hegemonic" states going back as far as Sung China (960-1279). ${ }^{2}$ In search of validation from history, they have associated demarcated periods (cycles) in instability and insecurity in world history with the absence of a hegemonic power capable of restoring some semblance of order to an otherwise malfunctioning system of interstate relations. ${ }^{3}$ Furthermore, and from entirely different perspectives, theorists of international relations and world systems have conceived of "systemic" pressures at work during periods of excessive violence, unacceptable predation and constant interruptions to commerce when states somehow collaborate to reorder geopolitical relations and, explicitly or implicitly, agree to comply with the rules and conventions set for the operation of a reformed system by leading powers of the day. ${ }^{4}$

Their best, indeed their only conceivable, example is the United Kingdom. Thus a paradigm has been constructed and widely accepted that, after an interregnum of interstate violence and neo mercantilism, from 1914-41, the United States succeeded to the benign hegemonic role that Great Britain had played in the geopolitical and economic order from the time of the French Revolution down to the Great War, 1914-18..$^{5}$ Analogies in the history of 
great power politics are not difficult to display. Nevertheless, this essay will substantiate the case that contrasts between the roles played by Britain (1793-1914) and the United States, (1941-2003) overwhelm superficial similarities. The argument is: that the contexts and circumstances in which these two great powers emerged and operated are singular and the commonplace representation of the Pax Britannica (or latterly, and even less plausibly, the British Empire) as a precedent and antecedent for the hegemony of the United States can be degraded into theory without history, and repositioned as a self serving myth, sustained by an Anglo-American political and intellectual elite who have gained most from propagating it since the Second World War.

\section{Geopolitical and Economic Preparations for American Hegemony}

Obvious contrasts appear immediately when the histories of the international relations preceding the assumption of "hegemony" by the United States and lets call it "primacy", by Britain are placed side by side. ${ }^{6}$ Before 1917 (and perhaps as late as 1941) the geopolitical context in which governments in Washington operated was virtually confined to the Americas north and south. In 1823, prompted by Canning (Britain's foreign secretary) President Monroe explicitly reserved the entire western hemisphere as a sphere of influence for the new Republic. ${ }^{7}$ Tacitly protected by the Royal Navy, from all further attempts at colonization by an Iberian, Dutch, French or any other European power seeking territory and wealth in the Americas, thereafter diplomatic confrontations between the United States and other powers were overwhelmingly with its wary and rejected mother country. Over Texas, Oregon, California, Venezuela, Panama, even Canada as well as the far more serious issue of the Confederacy, Governments in London invariably appeased Washington. ${ }^{8}$ After the War of 1812-14, Britain complied with Monroe's doctrine and the Royal Navy virtually enforced it because Britain's command of the seas meant that other European powers had no option but to allow federal governments in Washington to hold the Union together and 
to concentrate on formulating constitutional rules and enforcing legal codes for the highly effective exploitation of a sparsely populated continent, rich in natural resources, with enormous potential for economic growth. Even after the closing of the internal frontier and when the American navy moved (as European navies had done for centuries past) to secure the new nation's "home waters" by establishing bases (Puerto Rico, Cuba, Guam, Hawaii and the Philippines) out there in the blue waters of the Pacific and Atlantic oceans only Mexico, Spain (and in a farcical fashion, Napoleon III) challenged its manifest destiny and precocious ambitions to secure both continental and oceanic power. ${ }^{9}$

Meanwhile American business, operating within an evolving framework of law and institutions highly conducive to private enterprise, realized the potential inherent in the sparsely populated continent's massive and accessible endowments of fertile land and minerals quickly and effectively. That potential was already obvious to European observers before the War for Independence when labour productivity and per capita incomes were perhaps already close to British standards. ${ }^{10}$ Thereafter, the interaction of a constellation of highly favourable forces led to the almost inexorable growth of the economy. American success rested upon territorial expansion (some at the expense of France, Mexico and Russia); the exploitation of slave and black labour in the old south, rapid demographic growth complemented by a large influx of skilled, semiskilled, healthy adolescents from Europe; highly favourable and seemingly unlimited endowments of natural resources which attracted dominant shares of the funds available for investment on London and other European capital markets; and finally the diffusion of homogeneous tastes and mass markets, reinforced after the Civil War by an intensified process of ideological, linguistic, legal and cultural assimilation to the aims and aspirations of American capitalism. ${ }^{11}$ Unencumbered by social distinctions, protected from external aggression unhampered by problems of internal security, very lightly taxed and regulated, provided with ready access to European skills, capital and technology the integrated economy of the United States could hardly fail to grow more 
rapidly than the economies of its industrializing rivals in Western Europe. ${ }^{12}$ Shortly after the Civil War its national output exceeded the combined outputs of Britain, France and Germany. By the 1870 's there is little doubt that the United States offered the majority of its "white" citizens higher standards of living and prospects for upward mobility than anything available in Europe. By the 1890's the gap in real per capita incomes had become significant and it increased monotonically down to the middle of the twentieth century when convergence started to occur. Thus over the past half century the average differential in real incomes between Europe and the United States has narrowed from around 47\% to $62 \%$ but in scale and scope the American economy still remains larger and technologically more sophisticated than, the now integrating, European Union. ${ }^{13}$

No doubt Europeans have only themselves to blame for their failures to keep up and then catch up with the economy of the United States. Their barbaric and highly destructive civil wars 1914-18 and 1939-45 (separated by an interregnum of antagonism and neomercantilism 1919-39) surely accounts for more of Europe's relative retardation than any resort to crude binary comparisons which posit marked and permanently superior American technologies, scales of production, institutions, cultural values and other non-quantifiable factors included in the neo classical economist's repertoire of residual explanations under that elastic label of social capabilities? There were obstacles but never barriers to the diffusion of American know how. ${ }^{14}$ Furthermore, it is not clear when and how far the techniques and scales of production, designed to exploit the North American continent's rich portfolio of natural resources and to produce goods and services for mass consumption became optimally efficient for European industries let alone for its radically different range of agricultures to adopt. $^{15}$

Class struggles within, together with internecine warfare and imperial rivalry among European states, certainly held back the development of their economies and created the economic conditions as well as the political instability, predation and violence which 
encouraged and allowed for the emergence of a unique form of hegemony over a world in which "European power" had been on the rise since the Portuguese conquered Ceuta in 1415. Indeed the economic strength and the naval and military capacity required to assume such a role had already become apparent during the Great War, when the United States intervened late, and profitably, to prevent the Kaisereich from becoming the dominant power on the mainland and leaving, as the Germans suggested, Britain to continue as the preponderant power at sea. ${ }^{16}$

Thereafter, for roughly a quarter of a century, the American stance towards an international system of weaker, economically retarded, politically, unstable and mutually antagonistic powers vacillated between a retreat towards isolation (within its own already vast hemispheric sphere of influence and oceanic expanse of "home" waters) and the actions of a global hegemon in waiting. ${ }^{17}$

For example, after the Great War, America funded relief operations which helped towards the recovery of Europe. Furthermore, its plans (Young and Dawe's) represent laudable attempts to rebuild a stable monetary system. But on the negative side Washington's insistence on the full repayment of loans and credits, extended to help its allies to defeat the central powers, complemented more serious uncertainties surrounding the whole system of international exchange rates and the servicing of foreign debts after the most serious global war since Napoleon. Secondly, American rhetoric in favour of open trading was hardly congruent with the imposition of controls on immigration and protective legislation against imports passed by Congress. ${ }^{18}$ Finally (and most negative of all) came the Wall Street crash, followed by the collapse of the American banking system which led to the Great Depression (1929-32) and delivered a severe blow to a fragile international monetary system, to overseas trade and to a world economy recovering falteringly from the disruptions and interruptions that flowed from Europe's first great Civil War (1914-18). 
Although responsibility for triggering a crash connected to subsequent downturns in investment, production, trade and employment in most countries and sectors of the global economy continue to be debated, the view that the Great Depression constituted a political, as well as economic conjuncture in world history; that it originated in the United States and that the New Deal did little to assist recovery outside American borders remains tenable after more than 50 years of modelling and research in economics and economic history. ${ }^{19}$ Yet in the realm of political economy one medium term outcome of the depression was to reorder the perspectives of American elites responsible for the formation of economic policies effecting the vitality of their continental economy. Under Franklin Roosevelt their vistas widened to include the rest of the world, foreign trade, exchange rates and international financial flows as integrated components of their thinking about the economic interests of the United States. ${ }^{20}$

\section{The Rise of Britain}

Britain's rise to a status of "primacy" in a world dominated by European power politics looks very different. As rulers of a small not particularly advanced economy, located on an offshore island, the Tudor and Stuart regimes (1485-1688) had always taken full cognizance of their realm's place in a wider, largely European and Atlantic economy as well as its vulnerability to attacks and invasion from the sea. Before the Glorious Revolution they lacked the fiscal resources to play anything but a peripheral role in geopolitics on the mainland and relied on the sea together with a modest allocation of national resources to a partially privatized Royal Navy to defend their kingdom against external aggression. ${ }^{21}$ England's detached position in the hierarchy of contending European states and economies began to change after Civil War in the 1640's when its rulers (Republican and Royal alike) reconstructed a fiscal system capable of providing the state with taxes and loans required to invest in naval power, to hire mercenaries, subsidize military allies on the continent and to

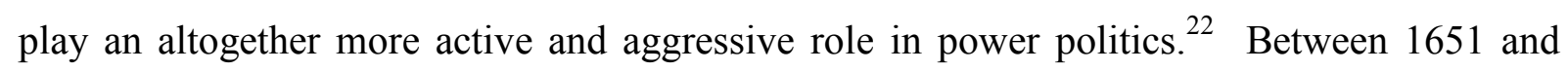


1802 the British state fought ten wars against major European rivals (the Netherlands, Spain and above all France) to maintain the security of the realm; to preserve its highly inegalitarian system of property rights; to jack up the nation's share of the gains from trade and profits from servicing an expanding global economy and to safeguard the kingdoms growing portfolio of assets: concessions, territories, natural resources and colonies in the Americas, Africa and Asia. $^{23}$

At the Congress of Vienna in 1815, (and after 22 years of warfare against Revolutionary and Napoleonic France) "Britons" emerged with a recently united Kingdom, with the largest navy in the world, the most extensive occidental expire since Rome; with extraordinary shares of the profits derived from overseas commerce and a domestic economy which stood half way through the first industrial revolution. Even then, in global terms, the economy of the realm remained small, but its exceptional endowments of fertile land, cheap energy and a skilled workforce (together with an extraordinary navy) had enabled the off shore island to reallocate more of its national resources to manufacturing industry and to convert inputs into outputs somewhat more efficiently than its main European rivals. ${ }^{24}$

Their problems in contending with the rise of Britain (1651-1815) emanated in part from inferior natural endowments (especially deposits of coal) and marginally weaker economies. Retardation persisted and widened because their fiscal and financial systems could not provide the mainland states of ancien regime Europe with the taxes and loans required to match British expenditures on naval and military power. Between 1688 and 1815 when real expenditures on its army and navy multiplied by a factor of 15 , while domestic product increased just three times, the Hanoverian state appropriated and borrowed a rising share of national resources which it used overwhelmingly to secure strategic, political and related economic gains. Neither France, Spain, the Netherlands nor any of Britain's competitors or clients could match London's ever expanding capacity to tax, borrow and spend on ships, arms and troops, basically because their fiscal constitutions and inefficient 
organizations for the assessment and collection of taxes constrained the powers of central governments (monarchical and oligarchical alike) to raise revenues. Furthermore, after three centuries of active engagement in state formation, reformation, wars of religion and imperial ventures overseas, by 1648 their fiscal systems had become almost impossible to reform. Resistance to their rulers ever increasing demands for revenues solidified and the capacities to tax and to borrow of most European states ran into diminishing returns. Thus in geopolitical terms the Hanoverian regime and its domestic economy benefited as a latecomer to power politics and rivalry for colonies and trade overseas. ${ }^{25}$

Then, and right at the end of the four centuries of mercantilism (1415-1815), the entire system of international relations was rent apart by nearly a quarter of a century of disruptive warfare associated with the French Revolution and the attempt of France to dominate continental Europe. When Napoleon's ambition was finally thwarted the British state, its fiscal and financial system, royal navy and domestic economy emerged from the most destructive of European conflicts in much better shape than the devastated economies, dilapidated fiscal bases and defeated armed forces of its rivals. Plenipotentiaries, gathered at the Congress of Vienna, to re-establish some kind of stable international order, recognized that the one clear outcome of the French Revolution had been to jack up British trade, commerce, finance, industry and naval power to unmistakable positions of primacy in Europe, Asia, Africa and the Americas. They looked to the recovery of their economies, the reconstruction of their fiscal and financial systems, the rebuilding of their armed forces and even supported the reconstruction of monarchical governance in France to bring back a balance of power that might preserve the status quo and check any latent British ambitions to exploit their economic naval and military weaknesses. ${ }^{26}$

Nevertheless - and despite the fact that Britain had cobbled together four coalitions, subsidized the armies of Austria, Prussia, Russia and several minor powers, committed troops to campaigns in Iberia and Flanders, provided the bulk of the naval power to defeat France 
and its allies at sea - when Napoleon was finally defeated no European state looked to Britain to play the role of hegemon. Furthermore, Britain's rulers never contemplated or presumed to occupy the place assigned to them retrospectively by social scientists whose theories implicitly "predict" that the systemic properties of a "Hegelian system" of international relations would prompt them and their rivals to do just that at the Congress of Vienna. ${ }^{27}$

\section{The Power of the United States 1941-2001}

Nothing like a post Vienna reversion to normal power politics after the chaos of a Revolutionary interregnum, 1789-1815, followed the second world war, when an alliance of states, dominated and heavily resourced by America had inflicted crushing defeats on Germany, Italy and Japan. Years before the historically unprecedented unconditional surrender of its enemies, Washington had already taken the lead in drawing up plans for the post war reconstruction of an international economic and political order that would avoid the division of the world economy into competitive and potentially antagonistic British, French, Dutch, Iberian and Russian empires. At the end of a destructive war for all its competitors when its mobilized economy had fully recovered from the long depression of the "thirties", the United States possessed fiscal capacity, financial strength, a benign history in power politics and above all the political confidence - acquired from managing an alliance (not a coalition) of powers that had won so decisive a victory over European fascism, and Japanese militarism. Washington was ready, able and willing to take the lead in promoting economic recovery and maintaining political stability. With Britain, (still afflicted by imperial responsibilities, delusions of grandeur and illusions of a special relationship), among leading supplicants for aid, only the Soviet Union (with strategic frontiers extended by the Red Army into the heartlands of central Europe) resisted American aspirations for a new international order. $^{28}$ 
Within a year the two opposed ideologies of communism and capitalism (latent but suppressed in wartime) led to the beginnings of a "cold war". For four decades, international relations became dominated by the division of the world into antagonistic coalitions of armed powers led by the Soviet Union on the one side and the United States on the other. Most other states explicitly, or tacitly, with varying degrees of solidarity, reluctance and episodes of disloyalty, opted to accept protection from the latter. In the middle of a barbaric century, at the end of empires and all pretensions that Europeans could provide more benign and civilized forms of alien rule for the indigenous populations of Asia, Africa and the Middle East, confident in their liberal ideology, historical record and capabilities to manage the international economic and geopolitical order an American (largely east coast) establishment offered governments and their citizens an alternative to fascism, communism and reincorporation into the Russian or some other European empire. Resistance to the exercise of a well-funded hegemony by a power ostensibly untainted by prior histories of imperialism and aggression in great power politics matured, despite the rhetorical stance taken by some third world leaders against American dominance, into tacit compliance. ${ }^{29}$

Clearly the defeated and occupied axis powers, Germany, Italy and Japan (as well as Fascist Iberia) had virtually no alternative to incorporation into a "Western" alliance. In addition scores of ethnically diverse countries, recently emancipated from colonial rule and preoccupied with state formation, the forging of national identities and economic development, also looked to Washington for all loans and credits they could obtain, particularly for the training and funding of their armed forces. Naturally conditionality became attached to programmes of aid funded and managed by Americans. ${ }^{30}$

Among European states only Britain and France maintained the stance, pretence and expense of possessing a spuriously "autonomous" nuclear capability. Aligned but also other non aligned "Bandung" powers (like India) made the plausible assumption that they were 
explicitly or implicitly part of a nuclear protectorate and that Washington would in the last resort defend them from threats of take over by the Soviet Union or by Communist China. ${ }^{31}$

Since 1941 the United States has signed up to an un-paralleled range of more or less comprehensive and costly agreements to defend the sovereignty and territorial integrity of an astonishing number of regimes of every conceivable political persuasion located on every continent. American taxpayers have now witnessed six decades of historically unprecedented levels of peace time expenditures to maintain garrisons, naval bases, airfields, carriers and fleets in every part of the world. The majority of the American electorate acquiesce and (with occasional lapses into scepticism) patriotically applaud the day to day involvement of their politicians, diplomats, armed forces and security services in the formulation, funding and execution of policies designed to protect far away and otherwise sovereign governments against threats of external aggression, internal subversion and latterly from terrorism. Presidential programmes defending the allocation of resources to contain communism, to isolate and occasionally to "degrade" potentially disruptive regimes (in Korea, Cuba, Vietnam, Nicaragua, Panama, Grenada, Libya, Sudan, Serbia, Afghanistan and now Iraq) usually attract an overwhelming national consensus. ${ }^{32}$

For a society with a long fiscal tradition of opposition to imperial and federal taxation, the ratios of national income appropriated in peace time by democratically elected governments for expenditures on strategic objectives have fluctuated up and down, but they have surely also remained at historically unprecedented levels?

Although Washington's fiscal base penetrates into a highly productive continental economy, America's hegemonic role could not and has not been sustained from tax revenues alone, even though economists and political scientists can usually be mobilized by Presidents to assure the electors that strategic commitments are necessary to obviate predictable and even higher levels of taxes that could surely follow from any reduction in America's expenditures in preserving stability for the international system as a whole. 
That kind of "expertise" is invariably useful to politicians but federal expenditures on strategic policy (which competes with multiple objectives more clearly linked to domestic welfare) has been covered only intermittently and partially by taxation. Budget deficits emerged during the war but persisted thereafter until well into the last decade of the $20^{\text {th }}$ century and have now reappeared during the war on terrorism.

Commitments to foreign and strategic objectives (often expensive to maintain) have also generated increasing governmental claims to the national economy's inflows and/or reserves of foreign currency. Unless their commitments are held in check governments must resort to borrowing on both domestic and on international capital markets, required in order to fund expenditures at home in dollars, and abroad in the currencies of other states, for the purchase of foreign goods, services and assets overseas.

For long stretches of the twentieth century American corporations and the federal governments in Washington experienced very little difficulty in obtaining access to the foreign exchange that funded governmental expenditures, private investment and all other economic transactions with Europe, South America, Asia and Africa. That felicitous reinforcement for the extension of hegemony overseas came about as an outcome of the status achieved by the dollar as the key currency within the international monetary system.

Key currencies held in the form of paper assets (bonds, bills, credit notes and cash) are issued as the liabilities of major states that foreign governments, banks, firms and households find cheap and relatively safe to hold in reserve as assets accumulating in value or for the convenience of conducting transactions with the rest of the world.

With the inexorable rise of the American economy and its attractions for foreign investors and immigrants, dollars became widely accepted as a "hard" currency that could be converted into the raw materials, foodstuffs, manufactured goods, services and other tradeables produced more efficiently and cheaply in the United States than anywhere else in the world. That competitive advantage became even stronger during periods of warfare and 
post-war recovery (1914-21) and (1939-52) when European, and Japanese rivals lacked the capacity or ability to engage in overseas trade. During these years, marked by the dollar problem, only dollars could buy a wide range of commodities and services demanded by rest of the world. That is why the conditions attached to loans, credits and aid extended by American banks, corporations and the federal government as well as satellite agencies of the United Nations could not be easily evaded by borrowing and buying elsewhere. ${ }^{33}$

Furthermore, under rules formulated in the state of New Hampshire in 1944, American voting rights and the dollar became entrenched in the constitution for a reconstructed international monetary system. Rules and conventions, designed to avoid the instabilities of trade and risks of overseas investment associated with floating, multiple and regulated exchange rate systems, which had appeared and persisted for three decades after 1914, obliged signatories to the Bretton Woods Agreement (who thereby gained access to loans and credits available from the I.M.F. and I.B.R.D) to fix and maintain more or less stable exchange rates with the dollar. This Bretton Woods' regime really came on stream with the restoration of convertibility after 1958 and as a international system of relatively fixed exchange rates only lasted to the oil crisis of 1971-73. Nevertheless, in constitutional terms it recognized and enshrined the dollar as the key currency for all international transactions and as the reserve asset for all national monetary systems signing up to the agreement. Bretton Woods augmented the status of the dollar and increased the willingness of foreign central banks, firms and investors to hold the national currency of the United States. ${ }^{34}$ For years after that famous agreement collapsed and dollars became unstable in value and fluctuated in relation to gold and other strong currencies such as the mark and yen, the status of the dollar continued to allow American corporations with nothing more than a "portfolio of paper assets" to purchase real wealth overseas. De Gaulle never tired of saying it also provided Washington with a "gold mine" of paper to fund its strategic policies - virtually free of all traditional budget and balance of payments constraints that had checked the ambitions of 
kings, aristocrats oligarchies and Napoleon's for centuries past. ${ }^{35}$ In their day ducats, guilders and pounds also served as key currencies but they never allowed the ruling elites of Genoa, Venice, Spain, the Netherlands or the United Kingdom to run deficits for as long and as consistently as governments in Washington. ${ }^{36}$

\section{The Power and Global Reach of the United Kingdom, 1793-1914}

Even Chicago economists recognize the need for some kind of international authority to formulate, revise and flexibly enforce rules for the conversion of currencies, the settlement of payments, the servicing and amortisation of international debt in order to facilitate the movement of goods, services, capital and knowledge across national frontiers. In some sense, but to a restricted political degree, the Bank of England performed those functions for roughly four decades before the First World War. But the Bank never declared or even implicitly accepted any responsibilities for the international monetary system as a whole and it hardly acted as a lender of last resort for British and imperial banks let alone for the banks and monetary systems of other foreign powers. ${ }^{37}$

By maintaining an unswerving adherence to full convertibility of its paper liabilities (at a parity that remained fixed between 1819 and 1914) the Bank acted basically as an example to other central banks of how to run a stable national system of paper credit. Of course Britain's prestigious economics profession could be relied upon to "prove" that strict adherence to the rules of the gold standard was the only rational way to run a national and a conjoined international monetary system that wished to avoid the "perils" of inflation and exchange rate instability. For liberals the gold standard restrained the aspirations of all governments (particularly autocrats) to run budget deficits and spend at levels and in ways that were contrary to the wishes of their citizens. ${ }^{38}$ Of course this message appealed to democrats, businessmen, creditors and foreigners who wished to raise funds on the London capital market. Although neither the Bank of England nor the Foreign Office conducted 
programmes to spread the gold standard, the Government resisted a political campaign to introduce bimetallism into Britain. Eventually and after the reunification of Germany, the political and economic appeal of linking paper currencies to gold led, but after the unification of Germany, to a rather slow spread of "a" gold standard around the world.

Nevertheless, and as more and more states linked, delinked and re-linked their currencies to gold between 1870 and 1914 and maintained sterling as a reserve asset, the policies that various national central banks adopted for the regulation of domestic money supplies, for interest rates, for the extension or contraction of credit and for relations with their own sovereign governments varied across the spectrum from mere expediency to pragmatic flexibility and disfunctional rigidity. ${ }^{39}$ Not only was there no paradigm set of rules for the regulation of national money supplies, the capacities of the Bank of England to even influence policies pursued by other central banks was in practice confined to the Dominions and colonies and to a sample of countries that maintained strong trading links with the United Kingdom.

Any presumed analogy to an orchestra of central banks conducted from London is without substance. Yet (and compared to the era of monetary and exchange rate instability that marked the decades after 1914) the pre-war international monetary system looked stable in retrospect. But the appeal of that lost "golden age" had much more to do with an absence of serious warfare, ideological competition, the integration of national economies through investments in railways, steamships and telegraphs and the virtual containment of "populist" demands for full employment and state welfare, than to any mythical properties embodied in a classical gold standard linked to a supposedly hegemonic and benign role played by the Bank of England in managing an international monetary system for the rest of the world. ${ }^{40}$

Finally (and this is a sharp contrast with America's federal reserve system) as Directors of a private corporation the Governors of the Bank never deferred or referred to the British Government when formulating or executing rules for the management of the national 
money supply. For their part successive cabinets never presumed that the status of sterling as a key currency and a reserve asset used by other economies provided the British state with any potential leeway let alone warrant for departures from that other golden rule of Victorian political economy - balanced budgets. Only occasionally on a very small scale (during Crimean and Boer Wars) did the state fail to cover its annual expenditures from tax revenues. These conjoined structural, ideological and fiscal constraints (an abiding political legacy of reaction to previous centuries of active engagement in power politics and mercantilism) provided Victorian and Edwardian statesmen with virtually no prospects for issuing paper pounds to fund any prolonged and extensive exercise of power. ${ }^{41}$

If "British hegemony" can be located anywhere in the historical record from 1793 to 1914 it appeared briefly - but largely in the guise of diplomacy and ideological persuasion rather than in the form of power - in the sphere of foreign trade. The kingdom's policy of diffusing open and free trade into an international economy prone to protectionism and degenerative bouts of mercantilism is (along with liberal navalism) historically famous. It first appeared as a geopolitical strategy after the American War of Independence under Pitt the Younger, went sharply into reverse during the last great European conflict of the mercantilist era (1793-1815) and was not even placed on the table at the Congress of Vienna in 1815. At that famous conjuncture in great power politics Castlereagh concentrated on securing a political settlement and no European state attempted to address the problem of reconstructing an international economic order. ${ }^{42}$

Nearly three decades later tariff reform and free trade then reappeared on Britain's own political agenda but almost entirely as an expedient designed to resolve a serious constitutional split between agrarian and other interests over the protection of grain farming. Britain's famous corn law controversy provided its aristocratic Tory and Whig elites with an opportunity to restrain demands for further constitutional reform, to tidy up the fiscal system, by restoring an income tax and helped them (too late in the day) to meet their responsibilities 
to Ireland by alleviating what was the most serious famine to afflict any European population during throughout the $19^{\text {th }}$ century. Ministers at the time of the "Hungry Forties" saw the repeal of both the corn laws and navigation acts along with imperial preferences as nothing more than a response to the United Kingdom's own social, constitutional, political and administrative problems. Neither Peel nor any other statesmen involved in the reformation of fiscal and commercial policy ever pretended to be offering "public goods" for the international economic order as a whole. ${ }^{43}$

Although the all powerful royal navy had not (as some powers had feared) been used to interfere with the trade of competitors (and Britain had even relinquished the right to interdict neutral shipping trading with its enemies in wartime) the subsequent formulation and implementation of a British diplomatic programme for the extension of open trading among nations matured slowly. That project really came on stream during the third quarter of the $19^{\text {th }}$ century as a sequence of bilateral treaties, which invariably included most favoured nation clauses. $^{44}$

Free trade (current in intellectual circles even before Adam Smith) then matured into the kingdom's enduring national ideology. Thereafter and down to the Ottawa agreements of 1932 the success of the Victorian and Edwardian economy, the stability of Britain's parliamentary constitution and the nation's status as a great power all became connected in the short term memories of politicians and the electorate to a "conjuncture" in domestic politics when home and imperial markets were opened up to foreign trade, competition and investment. Once again Britain's (second generation) of classical economists and their popularizers (like Cobden) could be mobilized to "demonstrate" rigorously (but for List and his followers hypocritically) that open trading was the only rational policy to pursue, not merely for their homeland and its vast empire, but for the rest of the world as well. For roughly three decades that message gained sympathy not merely among European and American liberals but with the autocratic rulers of France, Spain, Prussia and the Romanov 
and Habsburg Empires as well. Impressed with British economic success, anxious to avoid costly bouts of warfare, in search of cheaper food for their potentially disorderly urban working classes and short of revenues, they lowered tariffs. Smaller trading powers (Holland, Portugal and Switzerland) made moves in a British direction entirely congruent with their interests. "Clients" in South America found British pressures "irresistible". While the weak Qing, Ottoman, Tokugawa and Siamese empires could be intimidated by actual or threatened use of gun boat diplomacy. ${ }^{45}$

During a liberal interlude in world affairs, the British state took the lead and promoted open trade. Unfortunately for liberals that limited programme of persuasion, pressure and occasional use of naval power relapsed with the unification of Germany and the Franco Prussian War of 1870-71. Thereafter, in a more dangerous geopolitical climate marked by rearmament, the scramble for colonies in Africa and Asia and intensified competition on world markets for foodstuffs, primary produce and manufactured goods, British statesmen virtually withdrew from any active promotion of open trade on a global scale. Confronted with the revival of protectionism, they convened no international congresses to seek general agreements on trade, tariffs or commercial codes of conduct. Although the foreign office negotiated a few bilateral treaties to help British exports, the cabinet adhered rigidly to a "unilateralist" version of free trade, declined to "barter" and hoped that Britain's "moral" example and the transparent economic rationality of their policies would restrain the rising tide of nationalism and neo-mercantilism which had also, to their annoyance, surfaced in the Dominions. $^{46}$

Their persuasive defence of a popular tradition for free trade led the electorate to reject campaigns for fair trade, protection and for imperial preference, which might have provided the state with the sanctions required to bargain with France, Germany, America and other major powers for the preservation of an open trading regime. ${ }^{47}$ 
Even in the sphere of international relations that the British elite and the electorate at large (for economic and ideological reasons) cared most about, the imperial state in London remained circumspect and even timorous in the use of power (or any kind of American style strategic trade policy) to constrain the reversal to protectionism. Furthermore, those infamous episodes of gun boat diplomacy to prop up the Ottoman and open up the Qing Empires occurred largely for geopolitical reasons. The first as part of a strategy to contain the expansionist ambition of the Romanov empire. As for the second the British navy fought two "opium wars" to preserve the substantial revenues that the colonial government of India derived from taxing the export of hard drugs to China. ${ }^{48}$ In contrast the policies of the United States to maintain more open trade have surely relied less on diplomatic and ideological persuasion coupled with moral example and far more on sanctions mediated through the International Monetary Fund and the World Bank and above all on clear threats of retaliation against foreign exports to the world's richest market. ${ }^{49}$

Circumspection and acts of appeasement marked Britain's foreign and strategic as well as the country's commercial and monetary policies for most of the century after the Congress of Vienna. Although the Victorian state maintained a navy equal in scale and technical capability to the combined fleets of any two rival powers, had committed troops to the mainland during the closing years of the war against Napoleon and, before the rise of Germany, was recognized by other great powers as primus inter pares, the aristocratic elite in charge of foreign and imperial relations remained acutely aware of serious constraints on their capacities for decisive action overseas.

First and foremost (especially after Britain took over from the Mughal empire in India) they found themselves responsible for the day-to-day governance and defence of an enormous empire which included territories, assets and diverse populations on every continent. Year after year, and almost without forethought or permission from London, the frontiers of that Empire lengthened and bumped willy nilly against the borders or zones of influence crossed 
by railways and claimed as their spheres of operation by rival European and Asian powers in many parts of the world. What had been before 1815 a preoccupation with the security of the realm and the protection of overseas trade matured into responsibilities for a vulnerable and ever expanding empire from which there could be no escape and for which the size of the domestic economy and the fiscal base required for its management and defence remained woefully inadequate. ${ }^{50}$

Furthermore, the ever increasing amounts of fiscal and financial resources appropriated by the Hanoverian regime between 1688 and 1815 for the extension of empire, the protection of trade and the achievement of a geopolitical primacy were no longer available to its Victorian and Edwardian successors. After the enormous sums borrowed as loans and expropriated as taxes to defeat French ambitions to dominate Europe (1793-1815) any further and future accumulation of debt and extraction of taxes became extremely difficult for all $19^{\text {th }}$ century governments to persuade parliaments to sanction. To restore trust in aristocratic rule, sobriety, fiscal retrenchment, the repayment of debt, balanced budgets, laissez faire and treasury control became, along with a restrained extension of the franchise, akin to articles of an unwritten constitution. Britain's ancien regime survived right down to the Great War, but fiscally emasculated from any serious engagement in power politics, except for policies that could be presented as entirely necessary, but cheap expedients designed to preserve the security of the realm, defend an empire of "kith and kin" overseas and protect the nation's commerce with the rest of the world.

These underlying structural constraints on the size and actions of the state can be represented as the reflexive reactions to 164 years of mercantilism going back to Cromwell's first Anglo-Dutch war of 1651 which came to an ostensibly triumphant end with Nelson's victory at Trafalgar and Wellington's close run thing at Waterloo. Britain's heritage of successful mercantilism and imperialism matured into a historical myth of "old corruption"that sustained an ideology of distrust and antipathy towards the state among an 
expanding electorate and parliaments bent on constitutional reform, that cabinets of aristocrats in control of foreign policy could only contain by embracing prudence, parsimony and laissez faire. $^{51}$

Thus, there could be no resort to inflation of the money supply; very little borrowing and virtually no recourse to anything but cuts in and the rationalization of taxes. Not only were these structural parameters a requirement for restoring and sustaining trust for the continuation of aristocratic government, they allayed the fears among all men of property (landed commercial and industrial alike) who foresaw that extensions to the franchise would lead eventually to higher and potentially re-distributive taxation. ${ }^{52}$

Britain's unwritten fiscal constitution (which included rigid adherence to the gold standard, balanced budgets and laissez faire) goes a long way to account for the anxious and circumscribed role played by an ostensibly powerful state in international relations from 1815-1914. Foreign secretaries before Gray consistently avoided any entanglement in European power politics. They renounced all title to claims to territory (including Hanover) across the channel and British influence on the redrawing of frontiers, movements for national unification, democracy and independence on the mainland can be represented as largely diplomatic and rhetorical. Continental commitments of troops to theatres of war in Europe, North America and China were resolutely avoided, apart from that restricted conflict in the Crimea (1854-56) - regarded afterwards as a misallocation of troops and naval power to prop up the Ottoman Empire and to check Russian ambitions in the Balkans. ${ }^{53}$

Outside the Indian sub-continent and Africa, the deployment of British troops against the armies of other powers hardly occurred. When coercion was required to secure or defend a national objective, naval power was invariably the preferred option. But like air power today navies operated at a distance (offshore) which constrained what could be achieved by bombarding and degrading the coastal fortifications and ports of states and empires hostile to British interests. Even sea power was used with circumspection in order to preclude 
expensive naval arms races that had marked the long era of mercantilism $1415-1815 .^{54}$ Meanwhile for the defence and expansion of empire the British state relied on a corps of officers virtually privately funded and recruited for "service in the colours" from the aristocracy and gentry; on unskilled poorly paid white soldiers from the urban underclass and the Celtic fringe but depended overwhelmingly (in terms of numbers) upon a large army of Indian mercenaries - paid for from taxes collected in India - but drafted from time to time for imperial service in spheres of conflict beyond that sub-continent. Thus and (as ever apart from the Royal Navy) the "forces of the crown" were equipped up to, but not beyond, European standards of technical proficiency, managed by amateur or at best semi-professional officers, manned by an underclass of white troops and dominated in numerical strength by Indians - whose reliability after the Mutiny remained a matter of anxiety to Ministers in London as well as Viceroys in Delhi. ${ }^{55}$

Britain's military and naval basis for primacy depended far more on the persistent weakness of defeated European rivals (France, The Netherlands and Iberia) the absorption of Prussia and Piedmont, with the unification of Germany and Italy and the compensations of overland expansion derived by other rival territorial empires (run from St Petersburg, Vienna and Washington) than any extraordinary economic, military or cultural capabilities embodied in its own endowments, economy or institutions. Britain's position in great power politics continued to depend overwhelmingly on the Royal Navy, the decline of the Ottoman and Qing empires and the geopolitical preoccupations that prevailed and evolved within Europe for roughly a century after The Congress of Vienna. ${ }^{56}$

Aristocratic and imperial elites who ran the Victorian and Edwardian state seem, moreover to have been aware that any attempts to move forward from primacy to hegemony would be risky, expensive and (given the pressures for democracy) could lead to the demise of their adaptable, but essentially ancien regime. They appreciated that their privileged social 
and political position depended on a tradition of deference to birth and status that was passing with the years and required caution to preserve. ${ }^{57}$

\section{Conclusions: the Stark Contrasts between Primacy and Hegemony}

In comparative perspective the British ruling elite (and Palmerston enjoys historical fame as the "romantic" exception) realistically lacked the confidence displayed by the East Coast (and Texan!) Establishments since 1941 in the economic capacity and mission of the United States for the exercise of global hegemony. ${ }^{58}$ Although the far smaller British economy was progressive, the government's ability to appropriate revenues and raise loans ran into sharply diminishing returns, after the Napoleonic War. In their negotiations and diplomacy to maintain a balance of power and to attenuate envy of their country's stake in global commerce and colonies overseas, appeasement of major powers in Europe and North America seems to have been a constant in British foreign policy right down to its apogee in the 1930 's. ${ }^{59}$

The British elite represented their state as peaceful and tolerant, and themselves as democratic cultivated gentlemen. Liberals everywhere found them and their constitutional regime attractive. Nevertheless French "style" retained its established prestige and Albion was also widely regarded as "perfidious". While the urban degradation, yob like xenophobia and imperialistic jingoism of the English populace did not convey images of a culture that other societies found attractive to emulate. ${ }^{60}$

This particular and intangible contrast between Anglo and American cultures cannot be underestimated as a novel component of $20^{\text {th }}$ century power. For decades images of American standards of living, individualistic behaviour, as well as evidence of that republics military might and technological capabilities have been diffused rapidly to masses all over the world by modern media of communication: radio, television, films, the net, pop music and cheap travel. Such persuasive and seductive images of the United States continue to be 
disliked by intellectuals, mullahs, academics and nationalists of all kinds, because they erode religious, as well as local, communal and traditional identities that support rival states. ${ }^{61}$ Nevertheless the appeal of America to masses of people is clear and is conveyed to their leaders. Whenever and wherever societies aspire to become "modern", to enjoy higher incomes and to explore hedonistic life styles, then their cultures (and by implication their states and political elites) must somehow adapt to (if not accept) American values.

The emergence of cultural power certainly has historical roots and aspects of British liberalism, tolerance and science also possessed international appeal before 1914 . Nevertheless the significance of that kind of influence is distinctively modern and represents a discontinuity in international relations that is the product of mass consciousness, popular democracy and advanced media of communication. Cultural power provides Washington with a real supplement to its already massive economic and coercive powers, not merely to pay and compel others to do what the hegemon wants but to embrace what it wants. ${ }^{62}$

My essay suggests that the architecture of theories that represent the long term history of geopolitical relations in terms of a succession of hegemons lacks the bricks and the buildings of history to provide it with plausibility. Attempts to apply the concept or label of hegemon to the Genoese, Venetian and Dutch States let alone to Sung China) carry almost no conviction. In this essay I have argued that the classic or paradigm case of hegemonic succession from Great Britain to the United States can be degraded by a sequence of exercises in history designed to compare: the circumstances surrounding the emergence of both states to positions of leadership; by contrasting the economic, fiscal financial and cultural bases available to them to support the deployment of coercion and influence; by treating seriously the proclaimed intentions of two very different political elites and by examining the actual extent and ramifications of hegemonic power exercised by the United States since 1941 compared to Britain from 1793 to 1914; At the end of all that qualification, what seems to be left of hegemonic successions? What is the relevance of theory without history? ${ }^{63}$ 
First (and laudably!) a search for recurrent patterns in international relations that might be "imposed" on the long and complex history of great power politics in order to ascertain if the arenas in which states interact embody systemic variables that might give rise to periods (even cycles?) of stability and instability. Nevertheless, there remains a passing and possibly tendentious thought that Anglo-American intellectuals continue to find the notion of a tradition of civilized leadership of the world exercised by two English speaking states since 1815 entirely pleasing to contemplate and profitable to pursue. ${ }^{64}$ Yet whether they conceive of the geopolitical role played by their countries as benign or malign, the representation of the Pax Britannica as an antecedent or precedent for the Hegemony of the United States is virtually a myth. ${ }^{65}$

\footnotetext{
${ }^{1}$ Arrighi, G. and Silver, B.R. (eds.) (1999), Chaos and Governance in the Modern World System, Minnesota

2 Thompson, W.R. (2001), The Emergence of the Global Political-Economy, London

3 Gilpin, R. (1987), The Political Economy of International Relations, Princeton

4 Denemark, R.A. et al (eds.) (2000), World System History: the Social Science of Long Term Change, New York

5 Nye J. (1990), Bound to Lead, New York, and Kennedy, P. (1988) The Rise and Fall of the Great Powers, London

6 Kindleberger, C.P. (1996), World Economic Primacy 1500-1990, Oxford

7 Temperley, H. (2002), Britain and America Since Independence, Basingstoke

8 Allen, H.C. (1952), Great Britain and the United States: A History of Anglo-American Relations, 1783-1952, London

9 Traxel, D. (1998), The Birth of the American Century, New York

10 Vedder, R.K. (1976), The American Economy in Historical Perspective Belmont and Fogel, R.W. and Engerman, S.L. (eds.) (1971), The Reinterpretation of American Economic History, New York

11 Nelson, R and Wright, G. (1992), 'The Rise and Fall of American Technological Leadership: The Postwar Era in Historical Perspective', Journal of Economic Literature, 30, pp. 1931-64

12 Broadberry, S.N. (1997), The Productivity Race: British Manufacturing in International Perspectives 1850-1990, Cambridge

13 Maddison, A. (2001), The World Economy. A Millennium Perspective, Paris

14 Wright, G. (1990), 'The Origins of American Industrial Success, 1879-1940', American Economic Review, 80, pp. 651-68.
} 
15 Abramovitz, M. and David, P. (1996), 'Convergence and Deferred Catch-up' in Landau, D. et al (eds.) The Mosaic of Economic Growth, Stanford

16 Burk, K. (1984), Britain, America and the Sinews of War 1914-18, London

17 Maier, C. (1987), In Search of Stability. Explanations in Historical Political Economy, Cambridge

18 Zieburg, G. (1990), World Economy and World Politics 1924-31, Oxford

19 Bernstein, M. (1987), The Great Depression, Delayed Recovery and Economic Change in America 1929-39, Cambridge

20 Costigliola, F. (1984), Awkward Dominion: American Political and Cultural Relations with Europe 1919-33, Ithica

${ }^{21}$ Horn, D.B. (1967), Great Britain and Europe in the Eighteenth Century, Oxford

${ }_{22}$ Bonney, R. (ed.) (1995), Economic Systems and State Finance, Oxford

${ }^{23}$ O' Brien, P.K., 'Political Preconditions for the Industrian Revolution', in P.K. O'Brien and R. Quinault (ed.) (1993), The Industrial Revolution and British Society, Cambridge

24 Crouzet, F. (2001), A History of the European Economy 1000-2000, Virginia

25 O'Brien, P.K. (2002), 'Fiscal Exceptionalism. Great Britain and its European Rivals' in Winch, D. and O'Brien, P.K. (eds.), The Political Economy of British Historical Experience, Oxford

26 Holsti, K.J. (1991), Peace and War: Armed Conflicts and the International Order 1648-1989, Cambridge

27 Webster, C. (1963), The Congress of Vienna 1814-15, London

28 Maier, C. (1975), Recasting Bourgeois Europe, Princeton, N.J.

29 McCormick, T.J. (1995), American Half Century: U.S. Foreign Policy in the Cold War and Beyond

30 Milward, A. (1984), The Reconstruction of Western Europe 1945-51, London

31 Reynolds, D. (2000), One World Divisible. A Global History Since 1945, London

32 Hoffman, S. (1998), World Disorders, New York

33 Calleo, D. (1982), The Imperious Economy, Cambridge, MA.

34 Gardner, R.N. (1969), Sterling-Dollar Dipolomacy, Oxford

35 Tew, B. (1977), The Evolution of the International Monetary System, London

36 Kindleberger, C.P. (1973), World Economic Primacy, Oxford and Kindleberger, C.P. (1973) The World in Depression 1929-39, Berkeley

37 Winch, D. and O' Brien, P.K. (eds.) (2002), The Political Economy of British Economic Experience, Oxford

38 Fetter, F.W. (1965), Development of British Monetary Orthodoxy 1797-1875, Cambridge, MA.

39 Reis, J. (ed.) (1995), International Monetary Systems in Historical Perspective, Basingstoke

40 Braga, J. et al. (eds.) (1996), Currency Convertibility. The Gold Standard and Beyond, London and Eichengreen, B. (ed.) (1985), The Gold Standard in Theory and History, London

41 Walter, A. (1991), World Money and World Power: The Role of Hegemony and the International Monetary Order, New York

42 O' Brien, P.K. and Pigman, G.A. (1992), "Free trade, British hegemony and the international economic order in the nineteenth century" Review of International Studies, 18

43 Howe, A. (1997), Free Trade and Liberal England, Oxford

44 Semmel, B. (1986), Liberalism and Naval Strategy, Boston

45 Semmel, B. (1970), The Rise of Free Trade Imperialism, Cambridge

46 Bernstein, G.L. (1986), Liberalism and Liberal Politics in England, London

47 Friedberg, A. (1988), The Wary Titan: Britain and the Experience of Relative Decline, Princeton

48 Costin, W.C. (1968), Great Britain and China 1833-60, Oxford

49 Lindert, P.H., 'United States Foreign Trade and Trade Policy for the Twentieth Century' in S. Engerman and R. Gallman (eds) (1996), The Cambridge Economic History of the United States, Vol. 3, Cambridge

50 O'Brien, P.K., 'The Security of the Realm and the Growth of the Economy', in P. Clarke and C. Trebilcock (eds) (1997), Understanding Decline, Perceptions and Realities of British Economic Performance, Cambridge

51 Winch, D. and O' Brien, P.K. (eds.) (2002), The Political Economy of British Economic Experience, Oxford

52 Bernstein, G.L. (1986), Liberalism and Liberal Politics in England, London

53 Bourne, K. (1970), The Foreign Policy of Victorian England, Oxford

54 Cited by Kennedy, P. (1983), The Rise and Fall of British Naval Mastery, London

55 O' Brien, P.K. (1991), 'The Imperial component in the Rise and Decline of the British Economy' in M. Mann and F. Halliday (eds.), The Rise and Decline of Nations, Oxford

56 Chamberlain, M. (1988), 'Pax Britannica?', British Foreign Policy 1789-1914, London

57 Hyam, R. (1993), Britain's Imperial Century 1815-1914, Basingstoke 
58 Watt, D.C. (1996), Personalities and Politics, London

59 Friedberg, A. (1988), The Wary Titan: Britain and the Experience of Relative Decline, Princeton

60 Taylor, P.J. (1996), The Way the Modern World Works. World Hegemony Impasse, Chichester

61 White, D. (1996), The American Century, New Haven

62 Zunz, O. (1998), Why the American Century?, Chicago

63 Elman, C. and Elman M. (eds.) 1999, International History and International Relations Theory: Bridges and Boundaries, Cambridge, MA.

64 Watt, D.C. (1984), Succeeding John Bull: America in Britain's Place 1900-75, Cambridge

65 Barnett, C. (2001), The Verdict of Peace, Basingstoke. I am very grateful to Niall Ferguson for allowing me to read his unpublished paper, 'British Imperialism Revisited: The Costs and Benefits of Angloglobalization’ Stern School of Business, New York, 2003 


\section{CESifo Working Paper Series}

(for full list see www.cesifo.de)

960 Aaron Tornell and Frank Westermann, Credit Market Imperfections in Middle Income Countries, June 2003

961 Hans-Werner Sinn and Wolfgang Ochel, Social Union, Convergence and Migration, June 2003

962 Michael P. Devereux, Measuring Taxes on Income from Capital, June 2003

963 Jakob de Haan, Jan-Egbert Sturm and Bjørn Volkerink, How to Measure the Tax Burden on Labour at the Macro-Level?, June 2003

964 Harry Grubert, The Tax Burden on Cross-Border Investment: Company Strategies and Country Responses, June 2003

965 Kirk A. Collins and James B. Davies, Measuring Effective Tax Rates on Human Capital: Methodology and an Application to Canada, June 2003

966 W. Steven Clark, Using Micro-Data to Assess Average Tax Rates, June 2003

967 Christopher Heady, The 'Taxing Wages' Approach to Measuring the Tax Burden on Labour, June 2003

968 Michael P. Devereux and Alexander Klemm, Measuring Taxes on Income from Capital: Evidence from the UK, June 2003

969 Bernhard Eckwert and Itzhak Zilcha, The Effect of Better Information on Income Inequality, June 2003

970 Hartmut Egger and Josef Falkinger, The Role of Public Infrastructure for Firm Location and International Outsourcing, June 2003

971 Dag Morten Dalen and Trond E. Olsen, Regulatory Competition and Multi-national Banking, June 2003

972 Matthias Wrede, Tax Deductibility of Commuting Expenses and Residential Land Use with more than one Center, June 2003

973 Alessandro Cigno and Annalisa Luporini, Scholarships or Student Loans? Subsidizing Higher Education in the Presence of Moral Hazard, June 2003

974 Chang Woon Nam, Andrea Gebauer and Rüdiger Parsche, Is the Completion of EU Single Market Hindered by VAT Evasion?, June 2003 
975 Michael Braulke and Giacomo Corneo, Capital Taxation May Survive in Open Economies, July 2003

976 Assar Lindbeck, An Essay on Welfare State Dynamics, July 2003

977 Henrik Jordahl and Luca Micheletto, Optimal Utilitarian Taxation and Horizontal Equity, July 2003

978 Martin D. D. Evans and Richard K. Lyons, Are Different-Currency Assets Imperfect Substitutes?, July 2003

979 Thorsten Bayindir-Upmann and Frank Stähler, Market Entry Regulation and International Competition, July 2003

980 Vivek Ghosal, Firm and Establishment Volatility: The Role of Sunk Costs, Profit Uncertainty and Technological Change, July 2003

981 Christopher A. Pissarides, Unemployment in Britain: A European Success Story, July 2003

982 Wolfgang Buchholz, Richard Cornes, and Wolfgang Peters, On the Frequency of Interior Cournot-Nash Equilibria in a Public Good Economy, July 2003

983 Syed M. Ahsan and Panagiotis Tsigaris, Choice of Tax Base Revisited: Cash Flow vs. Prepayment Approaches to Consumption Taxation, July 2003

984 Campbell Leith and Jim Malley, A Sectoral Analysis of Price-Setting Behavior in US Manufacturing Industries, July 2003

985 Hyun Park and Apostolis Philippopoulos, Choosing Club Membership under Tax Competition and Free Riding, July 2003

986 Federico Etro, Globalization and Political Geography, July 2003

987 Dan Ariely, Axel Ockenfels and Alvin E. Roth, An Experimental Analysis of Ending Rules in Internet Auctions, July 2003

988 Paola Conconi and Carlo Perroni, Self-Enforcing International Agreements and Domestic Policy Credibility, July 2003

989 Charles B. Blankart and Christian Kirchner, The Deadlock of the EU Budget: An Economic Analysis of Ways In and Ways Out, July 2003

990 M. Hasham Pesaran and Allan Timmermann, Small Sample Properties of Forecasts from Autoregressive Models under Structural Breaks, July 2003

991 Hyun Park, Apostolis Philippopoulos and Vangelis Vassilatos, On the Optimal Size of Public Sector under Rent-Seeking competition from State Coffers, July 2003 
992 Axel Ockenfels and Alvin E. Roth, Late and Multiple Bidding in Second Price Internet Auctions: Theory and Evidence Concerning Different Rules for Ending an Auction, July 2003

993 Pierre Salmon, The Assignment of Powers in an Open-ended European Union, July 2003

994 Louis N. Christofides and Chen Peng, Contract Duration and Indexation in a Period of Real and Nominal Uncertainty, July 2003

995 M. Hashem Pesaran, Til Schuermann, Björn-Jakob Treutler, and Scott M. Weiner, Macroeconomic Dynamics and Credit Risk: A Global Perspective, July 2003

996 Massimo Bordignon and Sandro Brusco, On Enhanced Cooperation, July 2003

997 David F. Bradford, Addressing the Transfer-Pricing Problem in an Origin-Basis X Tax, July 2003

998 Daniel Gros, Who Needs Foreign Banks?, July 2003

999 Wolfram Merzyn and Heinrich W. Ursprung, Voter Support for Privatizing Education: Evidence on Self-Interest and Ideology, July 2003

1000 Jo Thori Lind, Fractionalization and the Size of Government, July 2003

1001 Daniel Friedman and Donald Wittman, Litigation with Symmetric Bargaining and TwoSided Incomplete Information, July 2003

1002 Matthew Clarke and Sardar M. N. Islam, Health Adjusted GDP (HAGDP) Measures of the Relationship Between Economic Growth, Health Outcomes and Social Welfare, July 2003

1003 Volker Grossmann, Contest for Attention in a Quality-Ladder Model of Endogenous Growth, August 2003

1004 Marcel Gérard and Joan Martens Weiner, Cross-Border Loss Offset and Formulary Apportionment: How do they affect multijurisdictional firm investment spending and interjurisdictional tax competition?, August 2003

1005 Burkhard Heer, Nonsuperneutrality of Money in the Sidrauski Model with Heterogeous Agents, August 2003

1006 V. Anton Muscatelli, Piergiovanna Natale, and Patrizio Tirelli, A Simple and Flexible Alternative to the Stability and Growth Pact Deficit Ceilings. Is it at hand?, August 2003

1007 Reto Foellmi and Josef Zweimüller, Inequality and Economic Growth: European Versus U.S. Experiences, August 2003

1008 James S. Costain and Michael Reiter, Business Cycles, Unemployment Insurance, and the Calibration of Matching Models, August 2003 
1009 Marco Runkel, Optimal Contest Design when the Designer's Payoff Depends on Competitive Balance, August 2003

1010 Donald O. Parsons, Torben Tranaes and Helene Bie Lilleør, Voluntary Public Unemployment Insurance, August 2003

1011 Rüdiger Pethig and Andreas Wagener, Profit Tax Competition and Formula Apportionment, August 2003

1012 Johan Willner, Privatisation and Public Ownership in Finland, August 2003

1013 Seppo Kari and Jouko Ylä-Liedenpohja, Taxation and Valuation of International Real Investments, August 2003

1014 James Heckman, Rosa Matzkin and Lars Nesheim, Simulation and Estimation of Hedonic Models, August 2003

1015 Biswa N. Bhattacharyay, Towards a Macro-Prudential Leading Indicators Framework for Monitoring Financial Vulnerability, August 2003

1016 J. Stephen Ferris and Stanley L. Winer, Searching for Keynes: With Application to Canada, 1870-2000, August 2003

1017 Massimo Bordignon, Luca Colombo and Umberto Galmarini, Fiscal Federalism and Endogenous Lobbies' Formation, August 2003

1018 Annette Alstadsæter, The Dual Income Tax and Firms'Income Shifting through the Choice of Organizational Form and Real Capital Investments, August 2003

1019 Peter Fredriksson and Bertil Holmlund, Optimal Unemployment Insurance Design: Time Limits, Monitoring, or Workfare?, August 2003

1020 Kashif S. Mansori, Following in their Footsteps: Comparing Interest Parity Conditions in Central European Economies to the Euro Countries, August 2003

1021 Christoph Borgmann and Matthias Heidler, Demographics and Volatile Social Security Wealth: Political Risks of Benefit Rule Changes in Germany, August 2003

1022 Kjell Erik Lommerud, Bjørn Sandvik and Odd Rune Staume, Good Jobs, Bad Jobs and Redistribution, August 2003

1023 Patrick Karl O'Brien, The Governance of Globalization: The Political Economy of Anglo-American Hegemony, 1793-2003, September 2003 